\title{
Pengaruh Kepuasan terhadap Loyalitas pada Pembelian Produk Fashion Muslim Melalui Marketplace Shopee
}

\author{
The effect of satisfaction on loyalty on the purchase of muslim fashion products through the Shopee \\ marketplace
}

\section{Yudha Trishananto}

Fakultas Ekonomi dan Bisnis Islam, Institut Agama Islam Negeri Salatiga

E-mail: yudhatrishananto@iainsalatiga.ac.id

\begin{abstract}
This research aims to understand the effect of consumer satisfaction on loyalty through trust as an intervening variable in purchasing Muslim Fashion products through the shopee market place. Steps to collect data with the help of a questionnaire through an interval scale. The sample obtained is 100 respondents through purposive sampling technique. The data is then processed through SmartPLS, analyzed through convergent validity, discriminant validity, composite reliability, average variance extracted (AVE), collinearity statistics (VIF), path coefficient test, goodness of fit test, hypothesis testing with bootstrap, then test moderation through SEM. Hypothesis testing on the satisfaction variable found a positive and significant effect on hedonic shopping value and utilitarian value. The trust variable has a positive and significant effect on hedonic shopping value and utilitarian shopping value. The satisfaction variable was found to have a positive effect on trust. The trust variable has a positive effect on loyalty and the satisfaction variable bas no effect on loyalty. The satisfaction variable was found to have an effect on loyalty through trust.
\end{abstract}

Keywords: hedonic shopping value, utilitarian shopping value, satisfaction, trust, loyalty

\section{Pendahuluan}

Teknologi informasi yang semakin tumbuh membuat strategi bisnis yang baru. Pembaruan bisnis yakni ditemukannya jual beli melalui media internet. Pemakaian internet ketika melakukan jual beli bisnis disebut sebagai e-commerce. Tingginya masyarakat Islami di Indonesia membuat langkah para pengusaha agar membuat usaha Fashion Muslim contohnya: jibab, baju, serta lainnya. Melalui e-commerce ketika memasarkan produk akan lebih efektif. Namun tingginya pengusaha online mengakibatkan perlombaandalam berdagang. Langkah agar memberi kepuasan yang dibutuhkan pelanggan dilalui pengusaha melalui banyak langkah agar pelanggan puas serta membeli kembali. Jika konsumen menjadi pembeli loyal karena merasa puasi, konsumen tidak lagi berganti pada produk lain (Selang A.D, 2017). Sesuai pada teori kepuasan marjinal, konsumen perlu memeperoleh rasa puas yang tinggi serta konsumen kemudian konsumen membeli produk untuk waktu yang lama, ketika telah memperoleh rasa puas dari produk sejenis yang digunakan. Kepuasan yang diperoleh sesuai pada marginal utility yang diturunkan dari pengeluaran yang sama kepada produk yang lain, dengan prtimbangan konsekuensi pada suatu pembelian.

Loyalitas online dibutuhkan sebab membei penawaran manfaat pada toko online, walaupum manfaat yang diperoleh sama pada yang didapatkan pasar off-line, tetapi kaitan kepuasan-loyalitas lebih tinggi pada dunia online dibandingkan offline. Rasa puas konsumen berkaitan pada pengalaman ketika membeli dahulu. Loyalitas yakni pembahasan penting bagi yang menjual pakaian elektronik sebab daerahnya lebih kompetitif dibandingkan yang dahulu, konsumen mempunyai strategi agar merrubah toko yang dipilih dengan bebas (Molinillo et al., 2017). 
Faktor yang dapat memberi pengaruh loyalitas konsumen yakni kepercayaan. Kepercayaan yakni langkah yang berguna saat memakai produk yang hendak dibeli konsumen. Kepuasan mempunyai dampak tidak langsung untuk loyalitas lewat kepercayaan. Maka kepercayaan dapat menjadi suatu mediasi kepuasan saat memberi peningkata loyalitas.

Kepuasan yakni suatu faktor yang membentuk tindakan konsumen, yang dapat diberi pengaruh oleh banyak faktor contohnya value. Aktivitas belanja konsumen dengan rasional, berarti konsumen membeli pada manfaat yang didapatkan produk dan sering dinamai utilitarian shopping value. Era digital sekarang aktivitas belanja diberi pengaruh nilai yang sifatnya emosional contohnya rasa nikmat serta rasa senang disebut sebagai hedonic shopping value (Hanzae, K., \& Rezaeyah, 2013b).

Penelitian muncul sebab ditemukan beda hasil penelitian yang lalu pendapat Ha et al (2010) pelanggan lebih serint kembali pada hal yang sama pengecer saat puas kepada pengalaman belanja terdahulu pada toko online. Lin et al (2015) bahwa pelanggan puas kemudian merasakan komitmen untuk perusahaan pengembangan ekonomi serta memberi keputusan setia apabila perusahaan menciptakan keinginan konsumen.

Molinillo et al (2017) bahwa tidak terdapat kaitan langsung kepuasan dengan loyalitas. Namun kaitan tidak langsung dibangun pada kepuasan serta loyalitas lewat kepercayaan serta nilai layanan yang diperoleh.

Penelitian ini beda dari penelitian yang lalu pada penelitian ini menyatukan variabel-variabel pada penelitian yang lalu yakni hedonic shopping value, utilitarian shopping value, kepuasan, kepercayaan serta loyalitas. Peneliti memilih variabel kepercayaan untuk variabel intervening. Objek yang dimanfaatkan yakni shopee sebab merupakan platform Marketplace yang terkenal di Asia Tenggara dalam kurun waktu kuartal I 2019 selain itu pengunjung kuartal II 2019 semakin naik rata-rata 8\% untuk setiap bulan (Reily, 2019).

Pada latar belakang serta beda hasil penelitian penulis memiliki keinginan meneliti tentang "Pengaruh Kepuasan Terhadap Loyalitas Pada Pembelian Produk Fashion Muslim Melalui Marketplace Shopee"

Penelitian ini terdapat rumusan masalah yakni: Bagaimana pengaruh antara hedonic shopping value serta utilitarian shopping value terhadap kepuasan konsumen? Bagaimana pengaruh antara hedonic shopping value, utilitarian shopping value serta kepuasan konsumen terhadap kepercayaan konsumen? Bagaimana pengaruh antara kepercayaan konsumen serta kepuasan konsumen terhadap loyalitas konsumen? Bagaimana pengaruh antara kepuasan konsumen terhadap loyalitas konsumen dengan kepercayaan sebagai variabel intervening?

Penelitian ini memiliki tujuan agar mengetahui pengaruh hedonic shopping value serta utilitarian shopping value terhadap kepuasan konsumen pada pelanggan shopee. Agar mengetahui pengaruh bedonic shopping value, utilitarian shopping value serta kepuasan konsumen terhadap kepercayaan konsumen pada pelanggan shopee. Agar mengetahui pengaruh kepercayaan konsumen serta kepuasan konsumen terhadap loyalitas konsumen pada pelanggan shopee. Agar mengetahui pengaruh kepuasan konsumen terhadap loyalitas konsumen melalui kepercayaan sebagai variabel intervening pada pelanggan shopee.

Manfaat penelitian ini yakni:

1) Manfaat teoritis untuk menambah pengetahuan terutama tentang loyalitas dalam membeli online.

2) Manfaat praktis

a) Untuk pelaku usaha untuk arahan mengembangkan usaha online ketika pemasaran.

b) Untuk penulis yakni langkah mengetahui pengaruh pada penelitian yang dilakukan

c) Untuk penelitian lanjutan agar memperoleh referensi untuk penelitian yang lain. 


\section{Kajian Pustaka}

\subsection{Teori Perilaku Konsumen}

Menurut Gilarso (1994) agar tahu sebab tindakan konsumen ketikamembeli, terdapat teori perilaku konsumen yang mampu memberi penjelasan yakni sebagai berikut:

a) Teori Ekonomi Mikro

Pada teori ini konsumen perlu memperoleh kepuasan tinggi serta konsumen selanjutnya melanjutkan pembelian untuk produk untuk jangka yang lama. Pada hal ini kepuasan yang didapatkan sebanding pada marginal utility diturunkan melalui pengeluaran yang sama kepada beberapa produk lain, lewat pertimbangan yang teliti kepada dampak pada pembeli.

b) Teori Psikologis

Teori psikologis yakni penerapan pada teori-teori dalam hal psikologis ketika melakukan analisa tindakan konsumen serta mendasarkan untuk hal-hal psikologis individu karena lingkungan.

c) Teori sosiologis

Teori ini lebih menitik beratkan pada hubungan dan pengaruh antara individu-individu yang dikaitkan dengan perilaku mereka jadi lebih mengutamakan perilaku kelompok dari pada perilaku individu.

\subsection{Perilaku konsumen}

Menurut Subianto (2007) perilaku konsumen yakni tingkah laku oleh individu, kelompok maupun organisaasi berkaitan pada langkah mengambil keputusan saat memperoleh, memakai produk maupun jasa ekonomis serta mampu dipengaruhi melalui lingkungan.

\subsection{Loyalitas}

Loyalitas pelanggan online yakni kemauan konsumen agar dapat bertahan pada hubungan konsisten yang akan datang serta agar berpartisipasi pada tindakan berkunjung kembali bertujuan agar produk maupun layanan online, memakai situs web perusahaan untuk langkah awal dari yang lain, didorong keyakinan yang memberi keuntungan serta emosi baik untuk perusahaan online Toufaily et al (2013). Dalam mengukur loyalitas konsumen menggunakan indikator: membeli kembali dengan rutin, konsumen membeli lagi produk dengan merek sama dari tawaran toko, pemikiran tidak membeli pada toko tersebut pada bulan-bulan selanjutnya, memberitahu masyarakat lain, pembeli berkomunikasi melalui mulut ke mulut (Sirohi et al., 1998).

\subsection{Kepuasan}

Kepuasan yakni kepuasan konsumen hubungannya pada pembelian yang lalu yang diberi oleh perusahaan electronic. Konsumen yang kurang sesuai akan mencari tahu langkah lain mengukur kepuasan dapat dengan menggunakan indikator: pengalaman setelah membeli, pengalaman sebelum membeli, pengalaman ketika melakukan pembelian (Molinillo, 2017).

\subsection{Hedonic shopping value}

Nilai belanja hedonis menjelaskan nilai diperoleh melalui pengalaman membeli terlepas pada tingkah laku berkaitan pada menyelesaikan kegiatan (Griffin et al., 2000). Mengukur hedonic shopping value dapat menggunakan indikator: nilai belanja hedonis menggambarkan seberapa besar hiburan belanja serta nilai emosional, pemilihan terkait pada pengalaman membeli, meningkatnya keinginan pada membeli, bebas, memenuhi fantasi, serta pelarian seluruhnya dapat mewakilkan pengalaman membeli dengan hedonis (Babin et al., 1994). 


\subsection{Utilitarian shopping value}

Nilai belanja utilitarian menjelaskan nilai berkaitan pada menyelesaikan tugas dari pengalaman membeli (Griffin et al., 2000). Mengukur utilitarian shopping value menggunakan indikator: nilai belanja utilitarian terbentuk saat produk diperlukan dapat didapatkan serta hal tersebut semakin tinggi sebab barang didapatkan lebih melimpah melalui jalan yang mudah, nilai utilitarian diperoleh saat mendapatkan produk yang dibutuhkan saat berbelanja (Griffin et al., 2000).

\subsection{Kepercayaan}

Kepercayaan yakni aset strategis dalam hal komersial serta bermanfaat untuk meraih sukses hubungan. Kepercayaan dapat mengurangi tidak pasti serta resiko, melalui peningkatan tersedianya penjualan (Rose et al., 2012). Mengukur kepercayaan dapat menggunakan rasa aman membayar $m$ commerce, rasa aman bertransaksi lewat $m$-commerce, rasa aman saat membayar, terlindunginya privasi pada m-commerce (Chong et al., 2012).

\subsection{Kerangka Penelitian}

Pada penelitian yang dilakukan diperoleh kerangka pemikiran:

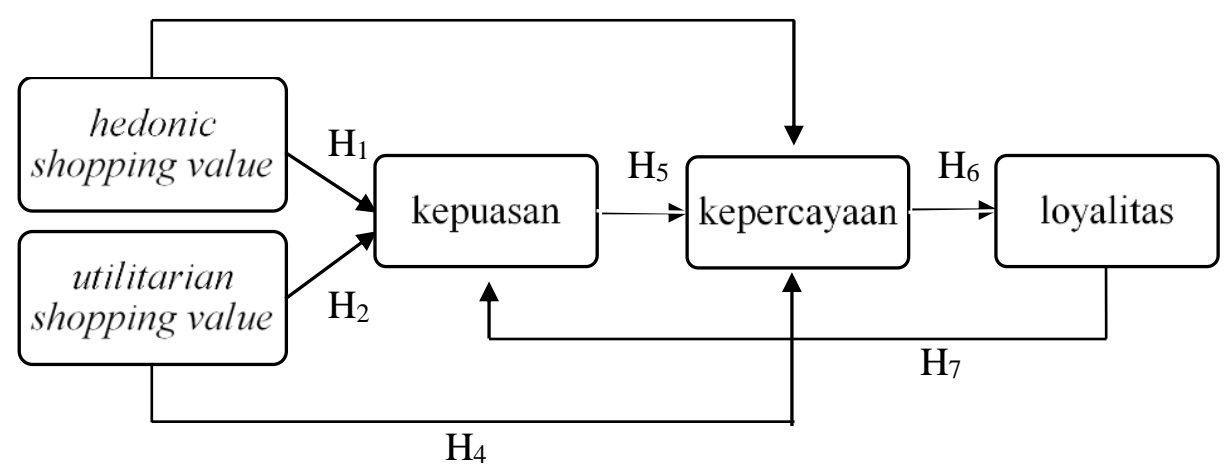

Gambar 1. Kerangka Pemikiran

\subsection{Hipotesis}

Penelitian Samirna, I., \& Zuhra (2016) terdapat kaitan positif hedonic value dengan kepuasan konsumen. Maka semakin meningkat hedonic value perusahaan artinya makin meningkat juga kepuasan. Sehingga diperoleh hipotesis yakni:

$H_{1}$ : Hedonic shopping value terdapat pengaruh positif serta signifikan terhadap kepuasan konsumen pada pembelian produk Fashion Muslim melalui marketpalce shopee.

Penelitian Hanzae, K., \& Rezaeyah (2013) utilitarian shopping value ditemukan hubungan dengan kepuasaan konsumen. Maka langkah kepuasan berkaitan tinggi kepada emosi berkaitan pada tempat belanja yang sesuai agar mmemperoleh nilai belanja hedonis akan mempunyai kaitan yang erat pada kepuasan pada nilai utilitarian. Sehingga diperoleh hipotesis yakni:

$\mathrm{H}_{2}$ : Utilitarian shopping value terdapat pengaruh positif serta signifikan terhadap kepuasan konsumen pada pembelian produk. Fashion Muslim melalui marketpalce shopee.

Penelitian Tahir, A., Karasakal, S., \& Kocabulut (2019) kualitas situs web memberi pengaruh nilai hedonis serta kepercayaan, akhirnya dapat memberi pengaruh loyalitas. Sehingga ditemukan kaitan signifikan pada karakteristik hedonis situs web serta kepercayaan. Sehingga diperoleh hipotesis yakni:

$H_{3}$ : Hedonic shopping value terdapat pengaruh positif serta signifikan terhadap kepercayaan konsumen pada 


\section{Yudha Trishananto}

pembelian produk Fashion Muslim melalui marketpalce shopee.

Penelitian Kim \& Hyun (2020) nilai utilitarian terdapat hubungan signifikan untuk komitmen serta kepercayaan. Maka utilitarian terdapat hubungan signifikan terhadap kepercayaan. Hipotesis yang diperoleh yakni:

$H_{4}$ : Utilitarian shopping value terdapat pengaruh positif serta signifikan terhadap kepercayaan konsumen pada pembelian produk Fashion Muslim melalui marketpalce shopee.

Penelitian Jin \& Kim (2008) konstruk kepuasan serta kepercayaan yakni berhubungan positif. Maka makin tinggi nilai kepusan konsumen makin tinggi juga kepercayaan konsumenuntuk toko. Hipotesis yang diperoleh yakni:

$H_{5}$ : Kepuasan terdapat pengaruh positif serta signifikan terhadap kepercayan pada pembelian produk Fashion Muslim melalui marketpalce shopee.

Penelitian Singh (1991) kepuasan yakni faktor yang terdapat pengaruh langsung kepada loyalitas konsumen. Maka makin tinggi nilai kepercayaan konsumen, makin tinggi juga nilai loyalitas konsumen. Hipotesis yang diperoleh yakni:

$H_{6}$ : Kepercayaan terdapat pengaruh positif serta signifikan terhadap loyalitas konsumen pada pembelian produk Fashion Muslim melalui marketpalce shopee.

Penelitian Jin \& Kim (2008) kepuasan terdapat hubungan positif terhadap loyalitas pelanggan pada e-commerce. Maka makin tinggi nilai kepuasan konsumen, makin tinggi juga nilai loyalitas konsumen. Hipotesis yang diperoleh yakni:

$H_{7}$ : Kepuasan terdapat pengaruh positif serta signifikan terbadap loyalitas konsumen pada pembelian produk Fashion Muslim melalui marketpalce shopee.

Penelitian Handayani (2016) kepuasan pelanggan terdapat kaitan signifikan terhadap kepercayaan serta loyalitas. Selanjutnya kepercayaan untuk mediator kaitan loyalitas serta kepuasan. Hipotesis yang diperoleh yakni:

H8 : Kepuasan terdapat pengarub positif serta signifikan terbadap loyalitas konsumen melalui Kepercayaan sebagai variabel intervening pada pembelian produk Fashion Muslim melalui marketpalce shopee.

\section{Metode Penelitian}

Penelitian yang dilakukan memakai penelitian deskriptif kuantitatif, diperoleh melalui kuesioner yang disebar kepada responden, selanjutnya dilakukan pengolahan serta analisis agar memperoleh informasi. Pada penelitian yang dilakukan menggunkan IAIN Salatiga untuk lokasi dalam penelitian. Populasi yang digunakan yakni semua mahasiswa IAIN Salatiga berjumlah 11.297 orang. Penelitian yang dilakukan memakai teknik nonprobability sampling yakni tidak seluruh bagian populasi memiliki kesempatan menjadi sampel melalui teknik purposive sampling memakai 100 responden. Penulis memakai data primer. Mengumpulkan data primer melalui penyebaran kuesioner dengan langsung untuk mahasiswa IAIN Salatiga.

\section{Hasil dan Pembahasan}

\subsection{Analisis Data}

\section{Model Pengukuran (Outer Model)}

Penelitian dilakukan melalui uji hipotesis memakai teknik analisis Partial Least Square (PLS) melalui bantuan smart PLS 3.0 Model skemanya yakni berikut ini: 


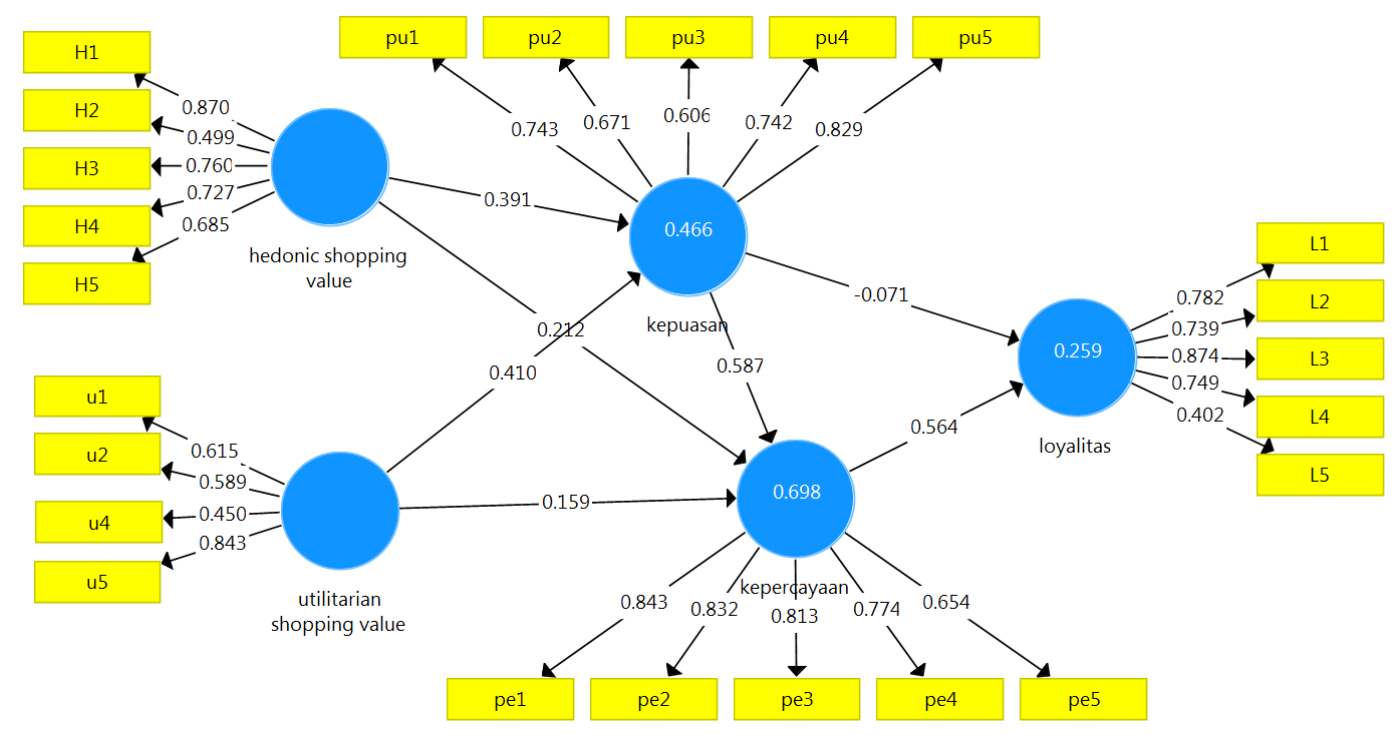

Gambar 2. Outer Model

Model tersebut menjelaskan kaitan variabel serta indikator-indikator yang dipakai. Outer model memberi penjelasan bagaimana setiap variabel berkaitan pada variabel laten uji yang pada outer model yakni:

\section{a) Convergent Validity}

Pada convergent validity dipakai besarnya outer loading maupun loading factor. Hasilnya yakni berikut ini:

Tabel 1. Outer Loading

\begin{tabular}{|c|c|c|}
\hline Variabel & Indikator & Outer Loadings \\
\hline \multirow{5}{*}{ Hedonic shopping value } & 1 & 0.796 \\
\hline & 2 & 0.583 \\
\hline & 3 & 0.708 \\
\hline & 4 & 0.699 \\
\hline & 5 & 0.753 \\
\hline \multirow{4}{*}{ utilitarian shopping value } & 1 & 0.526 \\
\hline & 2 & 0.725 \\
\hline & 4 & 0.935 \\
\hline & 5 & 0.831 \\
\hline \multirow{5}{*}{ Kepuasan konsumen } & 1 & 0.896 \\
\hline & 2 & 0.865 \\
\hline & 3 & 0.862 \\
\hline & 4 & 0.693 \\
\hline & 5 & 0.798 \\
\hline \multirow{5}{*}{ Kepercayaan konsumen } & 1 & 0.811 \\
\hline & 2 & 0.750 \\
\hline & 3 & 0.616 \\
\hline & 4 & 0.770 \\
\hline & 5 & 0.805 \\
\hline \multirow{2}{*}{ Loyalitas konsumen } & 1 & 0.869 \\
\hline & 2 & 0.808 \\
\hline
\end{tabular}




\begin{tabular}{|c|c|c|}
\hline Variabel & Indikator & Outer Loadings \\
\hline \multirow{4}{*}{} & 3 & 0.911 \\
\cline { 2 - 3 } & 4 & 0.746 \\
\cline { 2 - 3 } & 5 & 0.562 \\
\hline
\end{tabular}

Sumber: Output SmartPLS 3, data primer diolah, 2020

Sesuai tabel diatas setiap indikator variabel banyak yang mempunyai outer loading $<0,7$. Namun juga ada indikator yang mempunyai outer loading $>0,7$. Nilai outer loading 0,5-0,6 memenuhi persyaratan convergent validity (Chin, 1998).

b) Diskriminan Validity

Discriminant validity memakai nilai cross loading. Indikator dikatakan discriminant validity jika besarnya cross loading indikator yakni paling besar dibanding variabel yang lain. Nilainya yakni berikut ini:

Tabel 2. Cross Loading

\begin{tabular}{|c|c|c|c|c|c|}
\hline \multirow[b]{2}{*}{ Indikator } & \multicolumn{5}{|c|}{ Variabel } \\
\hline & $\begin{array}{c}\text { Hedonic } \\
\text { shopping } \\
\text { value }\end{array}$ & Kepercayaan & Kepuasan & Loyalitas & $\begin{array}{c}\text { Utilitarian } \\
\text { shopping } \\
\text { value }\end{array}$ \\
\hline H1 & 0.796 & 0.580 & 0.584 & 0.620 & 0.386 \\
\hline $\mathrm{H} 2$ & 0.583 & 0.127 & 0.101 & 0.199 & 0.012 \\
\hline $\mathrm{H} 3$ & 0.708 & 0.284 & 0.212 & 0.206 & 0.091 \\
\hline $\mathrm{H} 4$ & 0.699 & 0.345 & 0.415 & 0.464 & 0.120 \\
\hline $\mathrm{H} 5$ & 0.753 & 0.316 & 0.281 & 0.505 & 0.195 \\
\hline U1 & 0.305 & 0.443 & 0.276 & 0.437 & 0.526 \\
\hline $\mathrm{U} 2$ & 0.174 & 0.267 & 0.469 & 0.339 & 0.725 \\
\hline U4 & 0.173 & 0.513 & 0.570 & 0.506 & 0.935 \\
\hline U5 & 0.273 & 0.530 & 0.650 & 0.424 & 0.831 \\
\hline pe1 & 0.449 & 0.896 & 0.721 & 0.597 & 0.615 \\
\hline pe2 & 0.500 & 0.865 & 0.773 & 0.526 & 0.474 \\
\hline pe3 & 0.482 & 0.862 & 0.690 & 0.536 & 0.539 \\
\hline pe4 & 0.220 & 0.693 & 0.584 & 0.413 & 0.264 \\
\hline pe5 & 0.523 & 0.798 & 0.697 & 0.866 & 0.469 \\
\hline pu1 & 0.439 & 0.710 & 0.811 & 0.718 & 0.609 \\
\hline pu2 & 0.517 & 0.494 & 0.750 & 0.529 & 0.367 \\
\hline pu3 & 0.218 & 0.568 & 0.616 & 0.409 & 0.603 \\
\hline $\mathrm{pu} 4$ & 0.265 & 0.585 & 0.770 & 0.355 & 0.484 \\
\hline pu5 & 0.549 & 0.771 & 0.805 & 0.553 & 0.429 \\
\hline L1 & 0.558 & 0.710 & 0.699 & 0.869 & 0.586 \\
\hline L2 & 0.342 & 0.545 & 0.496 & 0.808 & 0.425 \\
\hline L3 & 0.526 & 0.621 & 0.571 & 0.911 & 0.454 \\
\hline L4 & 0.685 & 0.479 & 0.455 & 0.746 & 0.290 \\
\hline L5 & 0.403 & 0.482 & 0.486 & 0.562 & 0.363 \\
\hline
\end{tabular}

Sumber: Output SmartPLS 3, data primer diolah, 2020 


\section{Yudha Trishananto}

Sesuai hasil diatas besarnya cross loading indikator untuk variabel yang dipakai yakni yang paling besar dibanding variabel lain. Maka indikator yang dipakai mempunyai discriminant validity baik pada penyusunan setiap variabel.

c) Composite Reliability

Besar composite reliability pada setiap variabel yang dipakai yakni berikut ini:

Tabel 3. Composite Reliability

\begin{tabular}{|l|r|}
\hline \multicolumn{1}{|c|}{ Variabel } & Composite Reliability \\
\hline Hedonic shopping value & 0.835 \\
\hline Kepercayaan & 0.914 \\
\hline Kepuasan & 0.867 \\
\hline Loyalitas & 0.889 \\
\hline Utilitarian shopping value & 0.848 \\
\hline
\end{tabular}

Sumber: Output SmartPLS 3, data primer diolah, 2020

Besar composite reliability seluruh variabel pada penelitian $>0,6$. Maka setiap variabel memenuhi syarat composite reliability sehingga seluruh variabel mempunyai taraf reliabilitas tinggi.

d) Average Variance Extracted (AVE)

Konstruk mempunyai reliabilitas tinggi apabila AVE diatas 0,50 . Hasilnya yakni berikut ini:

Tabel 4. Average Variance Extracted (AVE)

\begin{tabular}{|ll|c|}
\hline \multicolumn{2}{|c|}{ Variabel } & AVE \\
\hline 1 & Hedonic shopping value & 0.506 \\
\hline 2 & Kepercayaan & 0.682 \\
\hline 3 & Kepuasan & 0.568 \\
\hline 4 & loyalitas & 0.622 \\
\hline 5 & utilitarian shopping value & 0.592 \\
\hline
\end{tabular}

Sumber: Output SmartPLS 3, data primer diolah, 2020

Dapat diamati besar AVE seluruh variabel $>0,50$ maka seluruh variabel reliabel.

\section{Evaluasi Inner Model}

Inner model maupun model struktural agar mengamati kaitan antara konstruk, taraf signifikansi serta R-square pada model penelitian. Model struktural dianalisis melalui $R$-square agar konstruk dependen uji t maupun signifikansi pada koefisien parameter jalur struktural. 
a) Uji path coefficient

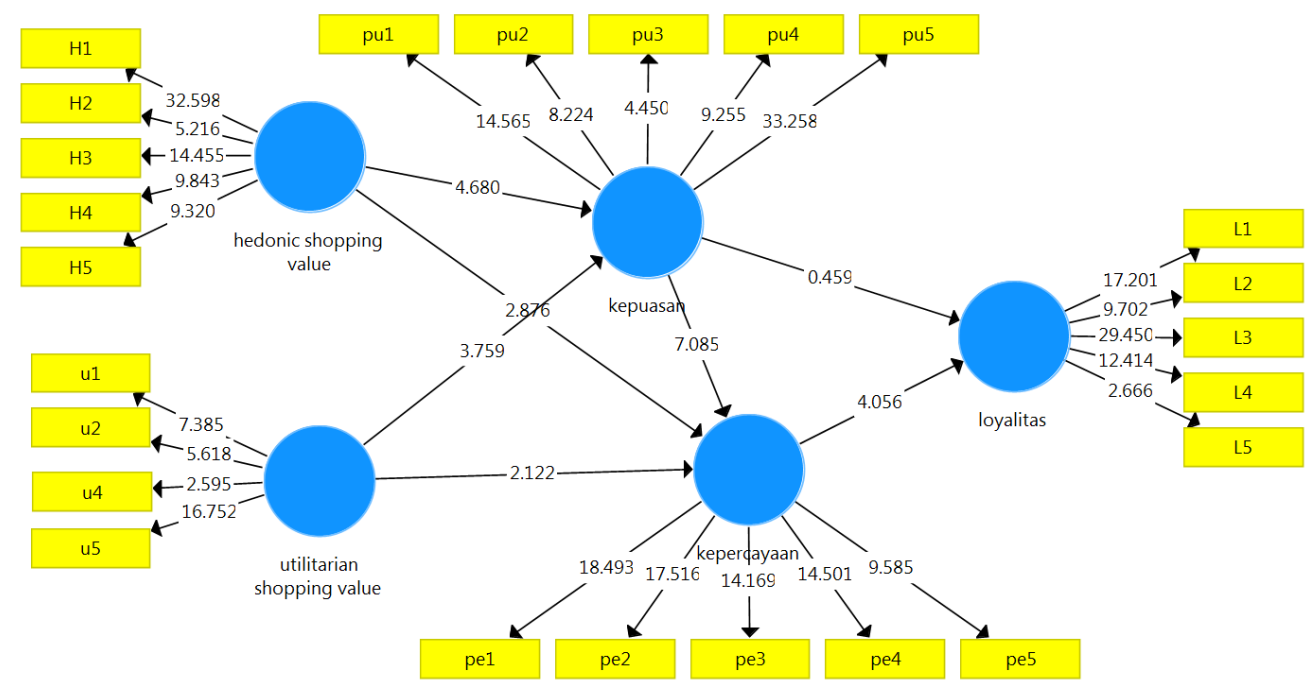

Gambar 3. Inner Model

Besar path coefficient paling tinggi pada pengaruh hedonic shopping value terhadap kepuasaan yakni 4,680. Besar path coefficient terkecil pada pengaruh kepuasan terhadap loyalitas yakni 0,459. Dapat dikatakan semua variabel pada penelitian mempunyai path coefficient pada angka positif. Artinya makin besar taraf path coefficient untuk satu variabel indepenen kepada variabel dependen, makin kuat juga pengaruh pada variabel independen terhadap variabel dependen.

b) Uji Goodness of fit

Sesuai pengujian, nilai $R$-Square adalah berikut ini:

Tabel 5. Nilai R-Square

\begin{tabular}{|l|r|}
\hline \multicolumn{1}{|c|}{ Variabel } & \multicolumn{2}{c|}{ R Square } \\
\hline Kepercayaan & 0.724 \\
\hline Kepuasan & 0.571 \\
\hline loyalitas & 0.561 \\
\hline
\end{tabular}

Sumber: Output SmartPLS 3, data primer diolah, 2020

Nilai R-Square kepercayaan yakni 0,724. Maka besar variabel kepercayaan yakni 72,4\%. Variabel kepuasan didapat R-Square sejumlah 0,571. Maka besar variabel kepuasan yakni 57,1\%. Serta variabel loyalitas yakni 0,561. Maka besar besar variabel loyalitas yakni 56,1\%.

Penilaian goodness of fit dilihat pada nilai Q-Square. Nilai Q-Square mempunyai makna sama pada coefficient determination (R-Square), makin tinggi Q-Square, model makin baik maupun makin fit pada data. Perhitungan $Q$-Square yakni berikut ini:

$$
\begin{gathered}
\text { Q-Square }=1-\left[\left(1-\mathrm{R}^{2} 1\right) \times\left(1-\mathrm{R}^{2} 2\right) \times\left(1-\mathrm{R}^{2} 3\right)\right] \\
=1-[(1-0,724) \times(1-0,571) \times(1-0,561)] \\
=1-(0,276 \times 0,429 \times 0,439) \\
=0,949
\end{gathered}
$$

Sesuai perhitungan nilai Square yakni 0,949. Maka besar perbedaan pada data penelitian model 
penelitian yakni 94,9\% lainnya sejumlah 5,1\% dijelaskan pada faktor lain diluar model penelitian. Artinya model penelitian mempunyai goodness of fit baik.

c) Collinearity Statistics (VTF)

Collinearity statistics diuji agar melihat kaitan antar indikator. Agar mengetahui apakah indikator terjadi multikolinierity yakni melihat besar VIF. Hasil pengujian collinearity statistics (VIF) yakni berikut ini:

Tabel 6. Outer VIF V alues

\begin{tabular}{|c|r|}
\hline Indikator & VIF \\
\hline H1 & 1.343 \\
\hline H2 & 1.790 \\
\hline H3 & 1.671 \\
\hline H4 & 1.582 \\
\hline H5 & 2.267 \\
\hline U1 & 1.654 \\
\hline U2 & 1.497 \\
\hline U4 & 3.796 \\
\hline U5 & 2.746 \\
\hline pe1 & 3.501 \\
\hline pe2 & 2.829 \\
\hline pe3 & 2.891 \\
\hline pe4 & 1.546 \\
\hline pe5 & 1.756 \\
\hline pu1 & 1.789 \\
\hline pu2 & 1.623 \\
\hline pu3 & 1.321 \\
\hline pu4 & 1.786 \\
\hline pu5 & 1.830 \\
\hline L1 & 2.675 \\
\hline L2 & 2.903 \\
\hline L3 & 4.367 \\
\hline L4 & 2.653 \\
\hline L5 & 1.248 \\
\hline Output & 2020 \\
\hline
\end{tabular}

Sumber: Output SmartPLS 3, data primer diolah, 2020

Seluruh indikator variabel memiliki nilai $<5$ maka seluruh indikator pada penelitian tidak ditemukan permasalahan multikolinierity.

\section{Uji Hipotesis}

Sesuai pengolahan data, dapat dimanfaatkan guna memberi jawaban hipotesis untuk penelitian. Uji hipotesis dilakukan melalui pengamatan besarT-Statistics serta besar P-Values. Uji hipotesis melalui inner model adalah berikut ini: 
Tabel 7. Result For Inner Weights

\begin{tabular}{|l|r|r|r|r|c|}
\hline \multicolumn{1}{|c|}{ Variabel } & $\begin{array}{c}\text { Original } \\
\text { Sample (O) }\end{array}$ & $\begin{array}{c}\text { Sample } \\
\text { Mean (M) }\end{array}$ & $\begin{array}{c}\text { Standard } \\
\text { Deviation } \\
\text { (STDEV) }\end{array}$ & $\begin{array}{c}\text { T Statistics } \\
(\mid \mathbf{O} / \text { STDEV|) }\end{array}$ & $\begin{array}{c}\text { P } \\
\text { Values }\end{array}$ \\
\hline $\begin{array}{l}\text { hedonic shopping } \\
\text { value -> kepuasan }\end{array}$ & 0.391 & 0.404 & 0.084 & 4.680 & 0.000 \\
\hline $\begin{array}{l}\text { utilitarian shopping } \\
\text { value -> kepuasan }\end{array}$ & 0.410 & 0.407 & 0.109 & 3.759 & 0.000 \\
\hline $\begin{array}{l}\text { hedonic shopping } \\
\text { value -> } \\
\text { kepercayaan }\end{array}$ & 0.212 & 0.205 & 0.074 & 2.876 & 0.004 \\
\hline $\begin{array}{l}\text { utilitarian shopping } \\
\text { value -> } \\
\text { kepercayaan }\end{array}$ & 0.159 & 0.164 & 0.075 & 2.122 & 0.034 \\
\hline $\begin{array}{l}\text { kepuasan -> } \\
\text { kepercayaan }\end{array}$ & 0.587 & 0.584 & 0.083 & 7.085 & 0.000 \\
\hline $\begin{array}{l}\text { kepercayaan -> } \\
\text { loyalitas }\end{array}$ & 0.564 & 0.578 & 0.139 & 4.056 & 0.000 \\
\hline $\begin{array}{l}\text { kepuasan -> } \\
\text { loyalitas }\end{array}$ & -0.071 & -0.071 & 0.154 & 0.459 & 0.647 \\
\hline
\end{tabular}

Sumber: Output SmartPLS 3, data primer diolah, 2020

Uji pada PLS dilakukan dengan statistik setiap kaitan yang dihipotesiskan dilakukan melalui simulasi. Maka dilakukan metode bootstrap untuk sampel. Uji melalui bootstrap agar memperkecil permasalahan tidak normal pada penelitian. Hasilnya adalah berikut ini:

Pengujian variabel hedonic shopping value terhadap kepuasan konsumen didapatkan besar p-value yakni $0,000<0,05$ artinya hedonic shopping value terdapat pengaruh positif serta signifikan terhadap kepuasan konsumen, pengaruhnya sejumlah 0,391.

Pengujian variabel utilitarian shopping value terhadap kepuasan konsumen didapatkan besar $p$ value yakni $0,000<0,05$ artinya utilitarian shopping value terdapat pengaruh positif serta signifikan terhadap kepuasan konsumen, pengaruhnya sejumlah 0,410.

Pengujian variabel hedonic shopping value terhadap kepercayaan konsumen didapatkan besar $p$ value yakni $0,004<0,05$ artinya hedonic shopping value terdapat pengaruh positif serta signifikan terhadap kepercayaan konsumen, pengaruhnya sejumlah 0,212.

Pengujian variabel utilitarian shopping value terhadap kepercayaan konsumen didapatkan besar p-value yakni 0,034 $<0,05$ artinya utilitarian shopping value terdapat pengaruh terhadap kepercayaan konsumen, pengaruhnya sejumlah 0,519 .

Pengujian variabel kepuasan terhadap kepercayaan didapatkan besar p-value sejumlah $0,000<$ 0,05 artinya kepuasan terdapat pengaruh positif signifikan terhadap kepercayaan konsumen, pengaruhnya sejumlah 0,587 .

Pengujian variabel kepercayaan terhadap loyalitas didapatkan besar p-value sejumlah $0,000<$ 0,05 artinya kepercayaan terdapat pengaruh positif signifikan terhadap loyalitas konsumen, pengaruhnya sejumlah 0,564 .

Pengujian variabel kepuasan terhadap loyaitas didapatkan besar $p$-value sejumlah $0,647>0,05$ 
kepuasan terdapat pengaruh negatif signifikan terhadap loyalitas konsumen.

Pengujian bootstraping PLS guna pengujian hipotesis kepuasan terhadap loyalitas melalui kepercayaan yakni berikut ini:

Tabel 8. Bootsraping

\begin{tabular}{|c|r|r|r|r|r|}
\hline Variabel & $\begin{array}{c}\text { Original } \\
\text { Sample (O) }\end{array}$ & $\begin{array}{c}\text { Sample } \\
\text { Mean (M) }\end{array}$ & $\begin{array}{c}\text { Standard } \\
\text { Deviation } \\
\text { (STDEV) }\end{array}$ & $\begin{array}{c}\text { T Statistics } \\
(\mid \mathbf{O} / \text { STDEV } \mid)\end{array}$ & P Values \\
\hline kepuasan -> loyalitas & 0.331 & 0.337 & 0.094 & 3.508 & 0.000 \\
\hline
\end{tabular}

Sumber: Output SmartPLS 3, data primer diolah, 2020

Besar p-value yakni $0,000<0.05$ maka kepuasan dengan tidak lansung terdapat pengaruh terhadap loyalitas, pengaruhnya sejumlah 0,331 .

Tabel 9. Specific Indirect Effects

\begin{tabular}{|l|r|r|r|r|r|}
\hline \multicolumn{1}{|c|}{ Variabel } & $\begin{array}{c}\text { Original } \\
\text { Sample (O) }\end{array}$ & $\begin{array}{c}\text { Sample } \\
\text { Mean (M) }\end{array}$ & $\begin{array}{c}\text { Standard } \\
\text { Deviation } \\
\text { (STDEV) }\end{array}$ & $\begin{array}{c}\text { T Statistics } \\
(\mid \mathbf{O} / \text { STDEV |) }\end{array}$ & P Values \\
\hline $\begin{array}{l}\text { kepuasan -> } \\
\text { kepercayaan -> } \\
\text { loyalitas }\end{array}$ & 0.331 & 0.337 & 0.094 & 3.508 & 0.000 \\
\hline
\end{tabular}

Sumber: Output SmartPLS 3, data primer diolah, 2020

Variabel kepuasan melalui tidak langsung memberi pengaruh variabel loyalitas. besar $p$-value $0,000<0,05$ maka kepuasan memberikan pengaruh variabel loyalitas melalui variabel kepercayaan.

\subsection{Pembahasan}

Pengujian variabel hedonic shopping value terhadap kepuasan konsumen didapatkan besar p-value yakni $0,000<0,05$ artinya hedonic shopping value terdapat pengaruh positif serta signifikan terhadap kepuasan pada pembelian produk Fashion Muslim melalui shopee pengaruhnya sejumlah 0,391, artinya H1 diterima. Sesuai penelitian Oktaviani (2017) bedonic value terdapat pengaruh positif terhadap customer satisfaction dari pengalaman makan pada restoran Carl's Jr Darmo Surabaya.

Pengujian variabel utilitarian shopping value terhadap kepuasan konsumen didapatkan besar $p$ value yakni $0,000<0,05$ artinya utilitarian shopping value terdapat pengaruh positif serta signifikan terhadap kepuasan konsumen pada pembelian produk Fashion Muslim melalui shopee, pengaruhnya sejumlah 0,410 artinya H2 diterima. Sesuai penelitian Yoo and Park (2016) besarnya utilitarian kemungkinan adalah variabel hasil yang berguna dapat memberi pengaruh keputusan konsumen agar mendapatkan kepuasan konsumen.

Pengujian variabel hedonic shopping value terhadap kepercayaan konsumen didapatkan besar $p$ value yakni $0,004<0,05$ artinya hedonic shopping value terdapat pengaruh positif serta signifikan terhadap kepercayaan konsumen pada pembelian produk Fashion Muslim melalui shopee pengaruhnya sejumlah 0,212, artinya H3 diterima. Sesuai penelitian Çal, B., \& Adams (2014) brand trust ditemukan pengaruh signifikan terhadap hedonic value.

Pengujian variabel utilitarian shopping value terhadap kepercayaan konsumen didapatkan besar p-value yakni $0,034<0,05$ artinya utilitarian shopping value terdapat pengaruh terhadap kepercayaan konsumen pada pembelian produk Fashion Muslim melalui shopee pengaruhnya sejumlah 0,519 artinya H4 diterima. Sesuai penelitian Kim (2020) besar utilitarian terdapat hubungan signifikan kepada komitmen serta kepercayaan. 
Pengujian variabel kepuasan terhadap kepercayaan didapatkan besar $p$-value sejumlah $0,000<$ 0,05 artinya kepuasan terdapat pengaruh positif signifikan terhadap kepercayaan konsumen pada pembelian produk Fashion Muslim melalui shopee pengaruhnya sejumlah 0,587 artinya H5 diterima. Sesuai penelitian $\mathrm{Ha}$ et al (2010) kepuasan terdapat hubungan tidak langsung kepada rasa setia melalui kepercayaan. Menunjukkan kepercayaan mampu menjadi mediator.

Pengujian variabel kepercayaan terhadap loyalitas didapatkan besar p-value sejumlah $0,000<$ 0,05 artinya kepercayaan terdapat pengaruh positif signifikan terhadap loyalitas konsumen pada pembelian produk fashion Muslim melalui shopee pengaruhnya sejumlah 0,564, artinya H6 diterima. Saat konsumen yakin kepada toko online akan menaikkan loyalitas konsumen untuk toko online, serta dapat memicu pembelian ulang di kemudian hari.

Pengujian variabel kepuasan terhadap loyaitas didapatkan besar $p$-value sejumlah 0,647>0,05 kepuasan terdapat pengaruh negatif signifikan terhadap loyalitas konsumen pada pembelian produk fashion Muslim melalui shopee, artinya H7 ditolak. Sesuai penelitian Hellier et al (2003) loyalitas tidak dengan langsung berkaitan kepada kepuasan serta preferensi merk yakni faktor yang menengahi antara kepuasan.

Pengaruh kepuasan terhadap loyalitas melalui kepercayaan sebagai variabel intervening Besar p-value yakni $0,000<0.05$ maka kepuasan dengan tidak lansung terdapat pengaruh terhadap loyalitas, pengaruhnya sejumlah 0,331 . Variabel kepuasan secara tidak langsung memberi pengaruh variabel loyalitas besar $p$-value $0,000<0,05$ maka kepuasan memberikan pengaruh variabel loyalitas melalui variabel kepercayaan. artinya H8 diterima. Sesuai penelitian Ha et al (2010) kepuasan mempunyai dampak tidak langsung untuk kesetiaan melalui kepercayaan. Maka kepercayaan mampu menjadi sebagai mediator kepuasan

\section{Penutup}

Sesuai hasil penelitian dapat diperoleh kesimpulan pada variabel kepuasan ditemukan pengaruh positif serta signifikan terhadap bedonic shopping value serta utilitarian value. Variabel kepercayaan ditemukan pengaruh positif serta signifikan terhadap bedonic shopping value serta utilitarian shopping value. Variabel kepuasan ditemukan pengaruh positif terhadap kepercayaan. Variabel kepercayaan ditemukan pengaruh positif terhadap loyalitas dan variabel kepuasan tidak ditemukan pengaruh terhadap loyalitas. Variabel kepuasan ditemukan pengaruh terhadap loyalitas melalui kepercayaan.

\section{Daftar Pustaka}

Babin, B. J., Darden, W. R., \& Griffin, M. (1994). Work and/or fun: Measuring Hedonic and Utilitarian Shopping Values. Journal of Consumer Research, 644-656.

Çal, B., \& Adams, R. (2014). The Effect of Hedonistic and Utilitarian Consumer Behavior on Brand Equity: Turkey - UK Comparison on Coca Cola. Procedia - Social and Behavioral Sciences, 475484.

Chong, A. Y., Chan, F. T., \& Ooi, K. B. (2012). Predicting Consumer Decisions to Adopt Mobile Commerce: Cross Country Empirical Examination Between China and Malaysia. Decision Support Systems, 5(3), 34-43.

Gilarso, D. T. (1994). Pengantar Ilmu Ekonomi Mikro. Kanisus Media.

Griffin, M., Babin, B. J., \& Modianos, D. (2000). Shopping Values of Russian Consumers: The impact of Habituation in a Developing Economy. Journal of Retailing, 7(6), 33-52.

Ha, H. Y., Janda, S., \& Muthaly, S. K. (2010). A new Understanding of Satisfaction Model in E-re-purchase Situation. 997-1016. 
Handayani, F. (2016). Kepercayaan sebagai Mediasi pada Pengaruh Kepusan Pelanggan terhadap Loyalitas Pelanggan. Fakultas Ekonomi Dan Bisnis Universitas Brawijaya.

Hanzae, K., \& Rezaeyah, S. (2013). Investigation to effect of Hedonic Value and Utilitarian Value on Costumer Satisfuction and Behavioural Intentions. African Journal of Business Management, 7(11), 818-825.

Hanzae, K., \& Rezaeyah, S. (2013b). Investigation to Effect of Hedonic Value and Utilitarian Value on Custumer Satisfuction and Behavioural Intentions. African Journal of Business Management, 7(11), 818-825.

Jin, B., Park, J. Y., \& Kim, J. (2008). Cross-Cultural Examination of the Relationships Among Firm Reputation, E-satisfaction, E-trust, and E-loyalty. International Marketing Review, 2(5), 324 337.

Kim, K., Choi, H.-j., \& Hyun, S. S. (2020). Coffee House Costomer Value Preparation and its Consequences: Multidimensional Approach. Sustainability.

Lin, C. H., Wu, C. W., \& Cheng, Y. H. (2015). The Empirical Study of Consumers' Loyalty for Display Technology. Journal of Business Research, 2260-2265.

Molinillo, S., Ortiz, B. G., Aranda, J. P., \& Garcia, A. N. (2017). Building Customer Loyalty:The Effect of ExperientialState, the Value of Shopping,and Trust and Perceived Valueof Service on Online Clothes Shopping. Sage Journal.

Oktaviani, Q. G. (2017). Pengaruh Hedonic Value dan Utilitarian Value terhadap Customer Satisfaction dan Behavioural Intentions. Jurnal Ilmiah Mahasiswa Universitas Surabaya, 6(2).

Reily, M. (2019). Cetak Penjualan Rp 54 T, Shopee E-Comerce Terpopuler di Asia Tenggara.

Rose, S., Clark, M., Samouel, P., \& Hair, N. (2012). Online Customer Experience in e-retailing: An Empirical Model of Antecedents and Outcomes. Journal of Retailing, 8(8), 308-322.

Samirna, I., \& Zuhra, S. (2016). Pengaruh Nilai belanja Hedonis dan Nilai BelanjaUtilitarian terhadap Loyalitas Destinasi Wisata dengan Kepuasan Belanja Ssecara Keseluruhan sebagai Variabel Mediasi pada Destinasi Wisata Kota Sabang. Jurnal Ilmiah Mahasiswa Ekonomi Manajemen, 1(1), 110-125.

Selang A.D, C. (2017). Bauran Pemasaran Marketing Mix Pengaruhnya Terhadap Loyalitas Konsumen Pada Fresh Mart Bahu Mall Manado... Jurnal EMBA, 71-78.

Singh, J. (1991). Understanding the Structure of Costomer Satisfaction Evalaluation off Service Delivery. Journal of Academy of Marketing Science, 19(3), 223-244.

Sirohi, N., McLaughlin, E. W., \& Wittink, D. R. (1998). A Model of Consumer Perceptions and Store Loyalty Intentions for a Supermarket Retailer. Journal of Retailing, 7(4), 223-245.

Subianto, T. (2007). Studi tentang Perilaku Konsumen Beserta Imlikasinya terhadap Keputusan Pembelian. Jurnal Ekonomi Modernisasi, 3(3).

Tahir, A., Karasakal, S., \& Kocabulut, Ö. (2019). Customer Loyalty Towards Travel Agency Websites:The Role of Trust and Hedonic Value. Journal of Quality Assurance in Hospitality \& Tourism.

Toufaily, E., Ricard, L., \& Perrien, J. (2013). Customer Loyalty to a Commercial Website: Descriptive meta- analysis of the Empirical Literature and Proposal of an Integrative Model. Journal of Business Research, 6(6), 1436-1447. 